\title{
Can the Incorporation of a Lead Foil on the Backside of Digital Receptors Produce a Better Endodontic Diagnosis?
}

\author{
¿Puede la Incorporación de una Lámina de Plomo en la Parte Posterior \\ de los Receptores Digitales Producir un Mejor Diagnóstico Endodóntico?
}

\author{
Eliana Dantas Costa1; Danieli Moura Brasil'1; Hugo Gaêta-Araujo²; Ana Caroline \\ Ramos Brito ${ }^{3}$; Christiano Oliveira-Santos ${ }^{4}$ \& Deborah Queiroz Freitas ${ }^{1}$
}

COSTA, E. D.; BRASIL, D. M.; GAÊTA-ARAUJO, H.; BRITO, A. C. R.; OLIVEIRA-SANTOS, C. \& FREITAS, D. Q. Can the incorporation of a lead foil to digital receptors make the endodontic diagnosis better?. Int. J. Odontostomat. 15(3):734-740, 2021.

\begin{abstract}
This study evaluated influence of addition of lead foil coupled to different types of digital receptors on image noise and on diagnosis of fractured instruments in teeth without and with root filling.Twenty-six molars had their root canals $(n=67)$ cleaned and shaped and were divided into groups with and without root filling and with and without fractured instruments. Images were acquired in PSP and CMOS sensor, with and without addition of a lead foil coupled to the digital receptors. Diagnostic values were obtained by the area under the ROC curve, and one-way ANOVA compared the groups. Noise in images was measured by the standard deviation of mean gray values in images with and without the lead foil, and compared by two-way ANOVA ( $a=0.05)$. Addition of lead foil did not interfere in the diagnostic accuracy for both digital systems $(p>0.05)$ and did not decrease noise in the images $(p>0.05)$. However, independently of the addition of the lead foil, the phosphor-storage plate presented higher noise compared to the sensor $(p \leq 0.05)$. Addition of lead foil to the digital receptor did not interfere in image noise and with the diagnostic accuracy for detecting fracured endodontic instrument in ex-vivo conditions.
\end{abstract}

KEY WORDS: endodontics; instrumentation; dentistry; radiography.

\section{INTRODUCTION}

Periapical radiographs are essential in endodontic treatment stages (i.e., diagnosis, planning, during treatment, and follow-up) (Rosen et al., 2016; Vasconcelos et al., 2017). Due to several radiographic exposures in endodontics, the development of digital radiographic systems allowed the optimization of this imaging technique with immediate image visualization and faster exam, generally with lower radiation exposure to the patient compared to conventional radiographs (Wenzel \& Møystad, 2010; Rosen et al., 2014; Nejaim et al., 2015; Vasconcelos et al.). The higher sensitivity of digital receptors provides a higher dynamic scale (range), and low radiation is required to achieve images with enough diagnostic quality (Wenzel \& Møystad; Rosen et al., 2014; Nejaim et al.).

Unlike conventional films, the digital system receptor does not present a coupled lead foil, which has a function of absorbing secondary/scatter radiation. A previous study (Nejaim et al.) verified that the addition of a lead foil coupled to the digital receptor absorbed part of the scatter radiation that would reach the patient, promoting greater radiation protection. Additionally, the reduction was greater for solid digital receptors (Nejaim et al.), which is the preferred receptor by endodontists (Oliveira et al., 2011). Aiming to evaluate the influence

\footnotetext{
${ }^{1}$ Division of Oral Radiology, Department of Oral Diagnosis, Piracicaba Dental School, University of Campinas, Piracicaba, SP, Brazil.

${ }^{2}$ Oral Radiology Area, School of Dentistry, Federal University of Alfenas, Alfenas, MG, Brazil.

${ }^{3}$ Health Sciences Center, Federal University of Piauí, Teresina, PI, Brazil.

${ }^{4}$ Department of Stomatology, Public Oral Health and Forensic Dentistry, School of Dentistry of Ribeirão Preto, University of São Paulo, Ribeirão Preto, SP, Brazil.
} 
of the incorporation of the lead foil to digital radiographic systems on radiographic diagnosis, a recent study (Farias Gomes et al., 2019) obtained promising data.In this study, although the lead foil did not influence the diagnosis of root fracture, the addition of the lead foil made pixel values of the image more uniform (decreases the fog).

In view of the above and considering that different diagnostic tasks have different performances depending on the imaging system, there is a need for further investigations regarding the use of the lead foil in different diagnostic tasks, especially in clinical situations where radiographic examinations are the method of choice, but have limitations that may impair the diagnosis and treatment plan.

Instrument fracture is among the most common complications in endodontics (Koç et al., 2018), which is more susceptible to occur in teeth with complex root canal morphology, or even in cases of inadequate or excessive instrumentation (Rosen et al., 2014; Koç et al.).Previous studies (Rosen et al., 2016; Ramos Brito et al., 2017; Koç et al.) found that fractured instrument detectionin teeth with root canal filling was superior using periapical radiographs compared to cone beam computed tomography (CBCT) images. However, although periapical radiography is the recommended imaging method for this clinical situation (Rosen et al., 2016; Ramos Brito et al.; Koç et al.), radiographic diagnosis in root canal filling is still one of the challenges in endodontics, due to similar radiopacity characteristics between the instrument and the filling material.

Thus, efforts need to be made to improve the performance of radiographic images, as well more information needs to be obtained about the use of the lead foil in different diagnostic tasks to provide better understanding of its influence. Thus, the aim of the present study was to evaluate the influence of the addition of lead foil coupled to different types of digital receptors on image noise and on diagnosis of fractured instruments in teeth without and with root filling. The hypothesis was that the addition of the lead foil would result in higher image quality and higher diagnostic values for the detection of fractured endodontic instruments.

\section{MATERIAL AND METHOD}

This study was approved by the local Institutional Review Board (CAAE: 99711018.3.0000.5418).
Study Sample. Twenty-six inferior molars (67 root canals), extracted for therapeutic reasons, were selected to compose the study sample. Teeth were inspected clinically and radiographically to verify the inclusion and exclusion criteria. Inclusion criteria consisted of teeth with closed apex and root curvature inferior to $5^{\circ}$ (Rosen et al., 2014), and exclusion criteria were teeth with previous endodontic treatment, pulp calcification, internal or external root resorptions, and root fractures.

Root canals were randomly divided into 4 groups according to the root canal condition (Fig. 1 and Table I). G1 to G4: Instrumentation of the root canals was performed for all teeth with a single-file (file R25, 25 $\mathrm{mm}$ - VDW, Munich, Germany), irrigation with $2.5 \%$ sodium hypochlorite and final cleaning with EDTA, and absorbent paper cone drying. G2 and G4: Obturation with gutta-percha cone (R25 cone, Reciproc, VDW, Munich, Germany) and zinc oxide-eugenol-based sealer (Dentsply Maillefer, Ballaigues, Switzerland). G3 and G4: Instrument inserted in apical third region.

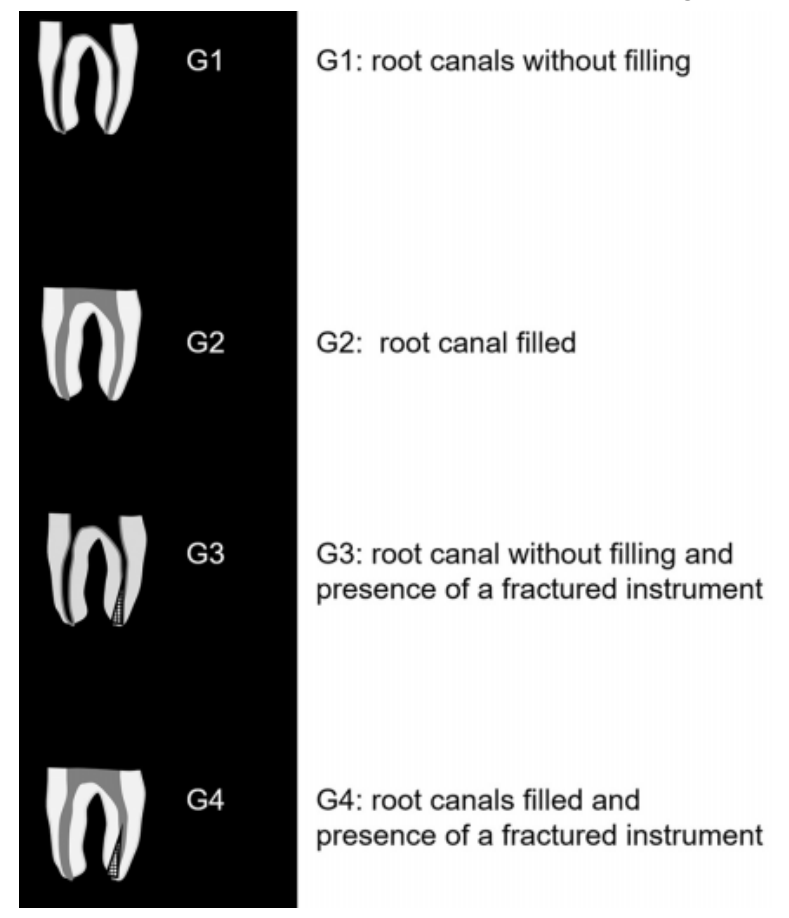

Fig. 1. Schematic representation of root canal division according to study groups. G1 to G4: Instrumentation of the root canals was performed for all teeth with a singlefile (file R25, $25 \mathrm{~mm}$ - VDW, Munich, Germany), irrigation with $2.5 \%$ sodium hypochlorite and final cleaning with EDTA, and absorbent paper cone drying. G2 and G4: Obturation with gutta-percha cone (R25 cone, Reciproc, VDW, Munich, Germany) and zinc oxide-eugenol-based sealer (Dentsply Maillefer, Ballaigues, Switzerland). G3 and G4: Instrument inserted in apical third region. 
COSTA, E. D.; BRASIL, D. M.; GAÊTA-ARAUJO, H.; BRITO, A. C. R.; OLIVEIRA-SANTOS, C. \& FREITAS, D. Q. Can the incorporation of a lead foil to digital receptors make the endodontic diagnosis better?. Int. J. Odontostomat. 15(3):734-740, 2021.

Table I. Division of root canals according to study groups.

\begin{tabular}{|c|c|c|c|c|}
\hline & $\begin{array}{c}\text { Group } 1 \\
(n=7)\end{array}$ & $\begin{array}{c}\text { Group } 2 \\
(n=8)\end{array}$ & $\begin{array}{c}\text { Group } 3 \\
(n=27)\end{array}$ & $\begin{array}{c}\text { Group } 4 \\
(n=26)\end{array}$ \\
\hline $\begin{array}{l}\text { Instrumentation of the root canals was performed for all teeth with } \\
\text { a single-file (file R25, } 25 \mathrm{~mm} \text { - VDW, Munich, Germany), irrigation } \\
\text { with } 2.5 \% \text { sodium hypochlorite and final cleaning with EDTA, and } \\
\text { absorbent paper cone drying }\end{array}$ & $\bar{X}$ & $\bar{X}$ & $\bar{X}$ & $\bar{X}$ \\
\hline $\begin{array}{l}\text { Instrument\# inserted in apical third region (D'Addazio et al., 2010; } \\
\text { Rosen et al., 2014; Rosen et al., 2016) }\end{array}$ & & & $X$ & $X$ \\
\hline $\begin{array}{l}\text { Obturation with gutta-percha cone (R25 cone, Reciproc, V DW, } \\
\text { Munich, Germany) and zinc oxide-eugenol-based sealer } \\
\text { (Dentsply Maillefer, Ballaigues, Switzerland) (Ramos Brito et al., } \\
\text { 2017) }\end{array}$ & & $X$ & & $x$ \\
\hline
\end{tabular}

\# The endodontic instruments used in the present study were: stainless steel hand files (Flexofile \#10, Dentsply Maillefer), NiTi reciprocating files (R25) and NiTi rotary files (ProTaper \#F1, Dentsply Maillefer).

For the root canals with the presence of fracture instruments, a wear was performed $2 \mathrm{~mm}$ from the apex of the instrument with the aid of a diamond bur (3203; KG Sorensen, Cotia, SP, Brasil), and the instrument was inserted in the apical foramen of the root and twisted to cause fracture (D'Addazio et al., 2011; Rosen et al., 2014, 2016). The endodontic instruments used in the present study was: stainless steel hand files (Flexofile \#10, Dentsply Maillefer), $\mathrm{NiTi}$ reciprocating files (R25) and NiTi rotary files (ProTaper \#F1, Dentsply Maillefer).

Phantom preparation. Each tooth was inserted individually in an empty alveolar socket of a dry mandible. The roots were covered with $0.3 \mathrm{~mm}$ of utility wax (NewWax Technew, Rio de Janeiro, RJ, Brazil) for periodontal ligament space simulation. To simulate the patient's tissue responsible for secondary radiation, a tongue-shape acrylic resin device was positioned behind the digital receptor. An entirety lead foil of a conventional film was coupled in the posterior surface of the image sensor and phosphor-storage plate.

Images acquisition. Images were acquired using an X-rays Focus unit (Kavo Dental, Brazil) and exposure parameters of $7 \mathrm{~mA}, 70 \mathrm{kVp}$, and $0.06 \mathrm{~s}$, according to previous study (Ramos Brito et al.).In addition, the parameters were tested in a pilot study using an aluminum stepwedge, to ensure the image quality between the systems. Since the dynamic scale of the PSP system is greater than that of CMOS, it was possible to use the same exposure time, maintaining similar gray values and without loss of image quality for the specific systems used in this study. Two digital radiographic systems were used: a direct complementary metal oxide semiconductor (CMOS) (Digora Toto - Soredex, Helsinki, Finland) size 2 (active area of $19.95 \times 30 \mathrm{~mm}$ and theoretical spatial resolution of 26.3 Ip.mm-1) and a phosphor-storage plate (PSP) (Express Instrumentarium Imaging, Tuusula, Finland), size 2 (active area of 31 x $41 \mathrm{~mm}$ and theoretical spatial resolution of 14.3 Ip.mm-1). An acrylic device was used to standardize image acquisitions, maintaining the mandible in position, the digital receptor parallel to the tooth long axis and ina $90^{\circ}$ angle with central X-ray beam, and a focus-receptor distance of $40 \mathrm{~cm}$. Buccal soft tissue was simulated with a $2.5 \mathrm{~mm}$-thick acrylic block (Vasconcelos et al.) (Fig. 2).

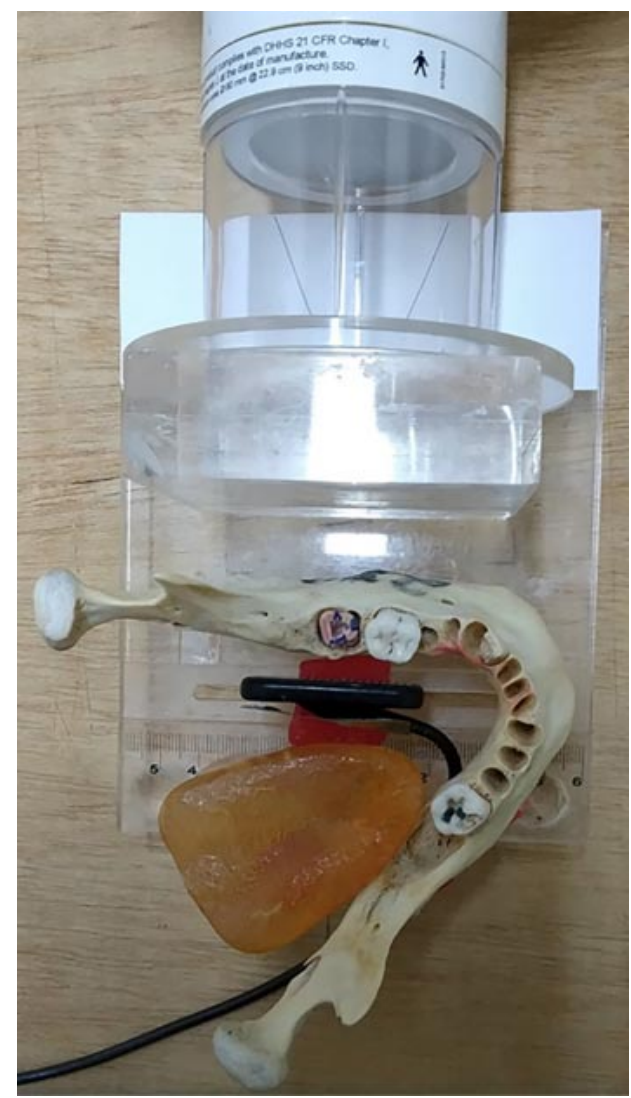

Fig. 2. An acrylic device used for image acquisition standardization and soft tissue simulation, and the positioning of the digital receptor, with a coupled lead foil, between the mandible and tongue-shaped acrylic device. The digital receptor was positioned with the transversal long axis parallel to the tooth long axis. 
In each tooth, 1,2 or 3 root canals were submitted to treatment, depending on their anatomy, totaling the 68 root canals evaluated in the study. Then, for image evaluation, the evaluators received an excel spreadsheet indicating which root canals should be evaluated in each radiographic set to avoid interpretations on root canals that were not included in the study. Each tooth was radiographed in three angles: orthoradial, mesioradial and distoradial, with an angle between them of $15^{\circ}$ (Rosen et al. 2014; Ramos Brito et al.). Thus, it was obtained:(26 ortorradial radiographs +26 mesial-radial radiographs +26 distal-radial radiographs) $\times 2$ systems $\times 2$ lead foil condition - with and without, totaling 312 images. Images were exported in TIFF format (Tagged Image File Format).

Image assessment. The set of the three images were randomized and individually assessed by five oral and maxillofacial radiologists in JPEG View software, with a black background. Brightness, contrast, and zoom tools could be freely used by the observers. The assessment was carried out in a dimly lit and calm room, in a 24" LCD monitor with 1920 x 1080 pixels resolution (Barco, Kortrijk, Belgium). The observers were asked to assess each root according to the presence of fracture instrument in a 5-point scale: 1 definitely absent; 2 - probably absent; 3 - uncertain; 4 -probably present; 5 - definitely present (Ramos Brito et al.). Thirty percent of the sample was re-assessed under the same conditions after thirty days to verify the intra-observer agreement.

To assess image quality, ten images with and ten images without the coupled lead foil were randomly chosen for each digital system. In these images, two regions of interest (ROI) of $2 \times 2 \mathrm{~mm}$ were set lateral and inferiorly to the tooth and noise was measured using ROI Manager tool of ImageJ software v1.51i
(National Institutes of Health, Bethesda, MD), which allowed all evaluations to be in exactly the same position (Fig. 3). Noise value was obtained by the standard deviation (SD) of the gray's values.

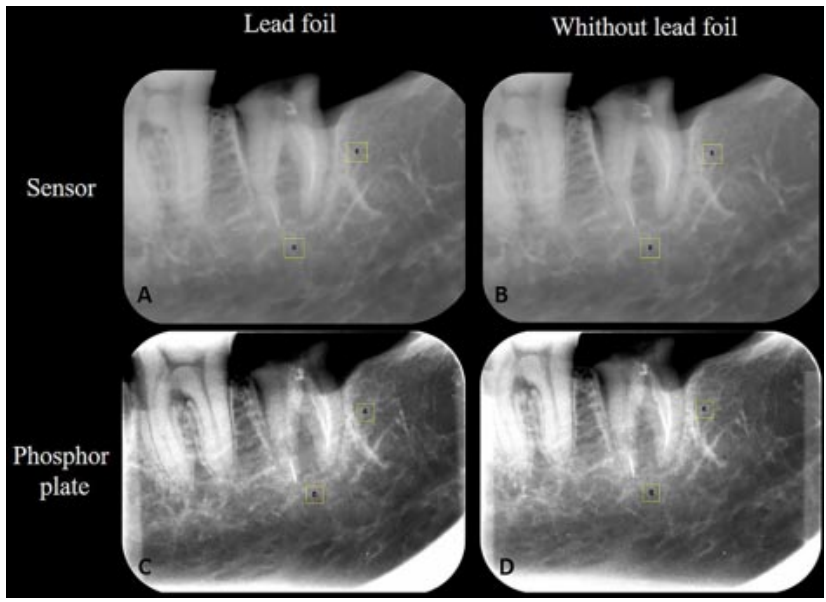

Fig. 3. Regions of interest set in inferior and lateral regions near the teeth. Images of the sensor system with $(A)$ and without lead foil (B). Images of phosphor plate system with (C) and without lead foil (D).

Statistical analysis. Intra and inter-observer agreement for fractured instrument detection were verified with weight-Kappa test and interpret according to Landis \& Koch (1977). The area under the Receiver Operating Characteristic (ROC) curve was used to calculate the diagnostic values of accuracy, sensitivity, and specificity. The diagnostic values of the different groups were compared using one-way ANOVA with Tukey's post hoc test. Image noise was compared by two-way ANOVA (digital systems $x$ coupled lead foil). For all analysis, a level of significance of $5 \%(a=0,05)$ was considered and performed in GraphPad Prism v7.0 software (GraphPad Software, La Jolla, CA) e MedCalc version 11.2.1.0 (MedCalc Software, Oostende, Belgium).

Table II. Mean values of accuracy, sensitivity, and specificity for endodontic fractured instrument detection in digital radiographic systems, with and without the coupled lead foil.

\begin{tabular}{lllll}
\hline Groups & & Accuracy & Sensitivity & Specificity \\
\hline PSP & In the absence of a root filling & & & \\
& Without lead foil & $0.625(0.07)$ & $0.544(0.08) \mathrm{A}$ & $0.933(0.09)$ \\
& With Lead foil & $0.644(0.04)$ & $0.600(0.05) \mathrm{A}$ & $0.833(0.20)$ \\
& In the presence of a root filling & & & $0.900(0.16)$ \\
& Without lead foil & $0.494(0.05)$ & $0.358(0.09) \mathrm{B}$ & $0.875(0.28)$ \\
& With Lead foil & $0.581(0.15)$ & $0.483(0.27) \mathrm{B}$ & $0.933(0.09)$ \\
Sensor & In the absence of a root filling & $0.663(0.08)$ & $0.600(0.10) \mathrm{A}$ & $0.867(0.22)$ \\
& Without lead foil & $0.613(0.12)$ & $0.554(0.12) \mathrm{A}$ & \\
& Lead foil & & & $0.950(0.07)$ \\
& In the presence of a root filling & $0.519(0.17)$ & $0.375(0.25) \mathrm{B}$ & $0.875(0.10)$ \\
\hline & Without lead foil & $0.508(0.17)$ & $0.386(0.26) \mathrm{B}$ &
\end{tabular}

Different letters indicate significant difference between filled and unfilled roots within each system. 


\section{RESULTS}

Intra-observer agreement was substantial (0.62$0.80)$ and inter-observer was weak to moderate $(0.20$ $0.59)$.

The results of diagnostic values showed that the addition of a coupled lead foil did not interfere in the accuracy, sensitivity and specificity, for both digital radiographic systems tested $(p>0.05)$ (Table II). A decrease in sensitivity was observed for both systems when the root canal was filled $(p \leq 0.05)$.

Regarding image quality, the addition of a coupled lead foil did not influence the image noise $(p>0.05)$ (Table III).

Table III. Quantification of noise measured by the standard deviations of mean gray values' standard deviations.

\begin{tabular}{ccccccc}
\hline & \multicolumn{2}{c}{ Sensor } & \multicolumn{4}{c}{ Phosphor plate } \\
& $\begin{array}{c}\text { Without lead foil } \\
\text { MVSD (SD) }\end{array}$ & $\begin{array}{c}\text { With lead Foil } \\
\text { MV SD (SD) }\end{array}$ & $P$ value & Without lead foil & WV With lead Foil \\
Orth oradial & & & & & & $P$ value \\
Inferior & $11.0(0.5)$ & $10.8(0.8)$ & 0.992 & $13.3(1.4)$ & $14.6(2.0)$ & 0.125 \\
Lateral & $15.0(0.6)$ & $15.0(0.4)$ & $>0.999$ & $13.4(2.8)$ & $13.6(1.6)$ & 0.998
\end{tabular}

Mean value of standard deviation, MVSD. Standard deviation, SD.

\section{DISCUSSION}

Confronted with the challenge of detecting endodontic fractured instruments by using digital periapical radiography associated to the patient protection to radiation dose action of lead foil by absorption of secondary/scatter radiation, the aim of this study was to evaluate the influence of the addition of a lead foil coupled to the digital receptor on the detection of fractured instruments in teeth without and with root filling. The lead foil did not influence that task, as also verified in a previous study, but in the diagnosis of root fracture by Farias Gomes et al.

However, unlike the study by Farias Gomes et al., in which an increase of the mean of gray values was observed, these data were not confirmed in the present study. This fact can be attributed to the fact that the previous study7used an acrylic phantom in the objective analysis that allows greater image homogeneity, where it was possible to verify subtle differences in the image, unlike the present study in which an attempt of reproducing a model of clinical condition. Thus, although in theory the lead foil would reduce the secondary radiation generated by the interaction with the soft tissues (tongue) that reaches the receptor (Nejaim et al.; Farias Gomes et al.), this fact was not observed since the presence of the lead foil did not influence the noise in the present study, which may explain the reason why did not improve the detection of fractured endodontic instruments. Still, according to Farias Gomes et al., the homogeneity in gray values obtained with the addition of the lead foil is subtle, this image characteristic may not be sufficient to influence the diagnosis.

In imaging exams, a high signal-to-noise ratio is fundamental for diagnostic tasks because it results in better image quality (Mehdizadeh et al., 2013). PSP presented higher noise in comparison to CMOS, regardless of the addition of lead foil. Such fact can be explained due to the difference in spatial resolution between the systems, as the sensor presents a greater number of line pair per millimeter compared to PSP (Ramos Brito et al.; Koç et al.). Although there was no significantly difference between the digital receptor for the detection of fractured instruments in non-filled canals, different characteristics of the receptor may justify a better precision of the sensor for this diagnostic task in cases of filled canals, which was previously confirmed by Ramos Brito et al.

Even though the sensor presented a more positive performance than the PSP, it is important to consider sensor's greater physical thickness, which is a factor responsible for generating greater secondary radiation to the patients' tissues (Nejaim et al.). Thus, since a negative effect was not also observed in the present study, the use of a coupled lead foil to the re- 
ceptor may be considered for additional radioprotection of the patients, including in cases of detection of fractured endodontic instruments.

When the professional uses the lead foil, special attention must be paid that the direct contact of lead to human especially in oral tissue should be avoided because of its toxicity (Nagasaka et al., 2018). Thus, it is emphasized that when the lead foil is used, it must be placed under the plastic barrier of the digital receiver. In addition, it is should also consider that environmental pollution should be taken into account for use and disposal.

Inferior molars were used in the present study because they can present a complex root canal morphology (Koç et al.). Due to the two-dimensionality of radiographic acquisition (Ramos Brito et al.; Sog ur et al., 2007), there is the a need to vary horizontal angle projections to promote mesial canals dissociation (Rosen et al., 2014; Ramos Brito et al.; Koç et al.; Sog ur et al.). Clinically,this condition would lead to higher radiation exposure to the patient (Sog ur et al.). Although periapical radiographs deliver low radiation doses, it is important to consider the possible occurrence of stochastic effects, which in essence, do not require a threshold dose to cause tissue damage at any dose (Nejaim et al.). The use of a lead foil represents additional care to reduce radiation reaching the patient, and as observed in the present study, does not alter the usual also maintain image quality for diagnosis, thus respect ALARA and ALADA principles (Jaju \& Jaju, 2015).

Anyway, as this attempt of modelisation of clinical conditions is still insufficient to generate all the scattering radiation that originates from the entire oral structures hitted by the primary beam, and as the use of lead foil does not alter the diagnostic capability as seen in this study, more studies with lead foil properly set in the back of the x-ray receptor (in waterproof enveloppe) should be conducted in real clinical conditions in order to check if this action can increase the diagnostic efficiency.

\section{CONCLUSION}

In conclusion, the addition of a coupled lead foil to the digital receptor did not influence image quality or the detection of fractured endodontic instruments in this ex vivo study. Therefore, it can be used as an alternative to protect patients without negative influence in that diagnosis, but the professionals should be aware that the lead foil cannot be in contact with oral tissues of the patient.

\section{ACKNOWLEDGMENTS}

The authors thank the Coordination for the Improvement of Higher Education Personnel (CAPES). This study was financed in part by the Coordenação de Aperfeiçoamento de Pessoal de Nível Superior (CAPES) - Finance Code 001.

COSTA, E. D.; BRASIL, D. M.; GAÊTA-ARAUJO, H.; BRITO, A. C. R.; OLIVEIRA-SANTOS, C. \& FREITAS, D. Q. ¿Puede la incorporación de una lámina de plomo en la parte posterior de los receptores digitales producir un mejor diagnóstico endodóntico? Int. J.Odontostomat., 15(3):734740, 2021.

RESUMEN: Este estudio evaluó la influencia de láminas de plomo acopladas a diferentes tipos de receptores digitales sobre el ruido de la imagen y el diagnóstico de instrumentos fracturados en dientes sin y con obturación radicular. Se limpiaron y moldearon 26 molares $(n=67)$, se dividieron en grupos con y sin relleno radicular y con y sin instrumentos fracturados. Las imágenes se adquirieron en el sensor PSP y CMOS, con y sin adición de una lámina de plomo acoplada a los receptores digitales. Los valores diagnósticos se obtuvieron por el área bajo la curva ROC y con ANOVA de una vía comparó los grupos. El ruido en las imágenes se midió mediante la desviación estándar de los valores medios de gris en las imágenes con y sin la lámina de plomo, y se comparó mediante ANOVA bidireccional $(a=$ $0,05)$. La adición de lámina de plomo no interfirió en la precisión diagnóstica de ambos sistemas digitales $(p>0,05)$ y no disminuyó el ruido en las imágenes ( $p>0,05)$. Sin embargo, independientemente de la adición de la lámina de plomo, la placa de almacenamiento de fósforo presentó mayor ruido en comparación con el sensor $(p \leq 0,05)$. La adición de lámina de plomo al receptor digital no interfirió con el ruido de la imagen y con la precisión diagnóstica para detectar el instrumento endodóntico fracturado en condiciones ex vivo.

PALABRAS CLAVE: endodoncia; instrumentación; odontología; radiografía.

\section{REFERENCES}

D'Addazio, P. S.; Campos, C. N.; Özcan, M.; Teixeira, H. G.; Passoni, R. M. \& Carvalho, A. C. A comparative study between cone-beam computed tomography and periapical radiographs in the diagnosis of simulated endodontic complications. Int. Endod. J., 44(3):218-24, 2011. 
Farias Gomes, A.; Nejaim, Y.; Fontenele, R. C.; Haiter-Neto, F. \& Freitas, D. Q. Influence of the incorporation of a lead foil to intraoral digital receptors on the image quality and root fracture diagnosis. Dentomaxillofac. Radiol., 48(6):20180369, 2019.

Jaju, P. P. \& Jaju, S. P. Cone-beam computed tomography: Time to move from ALARA to ALADA. Imaging Sci. Dent., 45(4):263-5, 2015.

Koç, C.; Sönmez, G.; Yılmaz, F.; Karahan, S. \& Kamburog`lu, K. Comparison of the accuracy of periapical radiography with CBCT taken at 3 different voxel sizes in detecting simulated endodontic complications: an ex vivo study. Dentomaxillofac. Radiol., 47(4):20170399, 2018

Landis, J. R. \& Koch, G. G. An application of hierarchical kappatype statistics in the assessment of majority agreement among multiple observers. Biometrics, 33(2):363-74, 1977.

Mehdizadeh, M.; Khademi, A. A.; Shokraneh, A. \& Farhadi, N. Effect of digital noise reduction on the accuracy of endodontic file length determination. Imaging Sci. Dent., 43(3):185-90, 2013.

Nagasaka, T.; Izumi, M.; Gotoh, K.; Kuwada, T.; Kise, Y.; Katsumata, A. \& Ariji, E. Use of tungsten sheet as an alternative for reducing the radiation dose behind the digital imaging plate during intraoral radiography. Dentomaxillofac. Radiol., 48(1):20180161, 2018.

Nejaim, Y.; Silva, A. I.; Brasil, D. M.; Vasconcelos, K. F.; Haiter Neto, F. \& Boscolo, F. N. Efficacy of lead foil for reducing doses in the head and neck: a simulation study using digital intraoral systems. Dentomaxillofac. Radiol., 44(8):20150065, 2015.

Oliveira, M. L.; Ambrosano, G. M.; Almeida, S. M.; Haiter-Neto, F. \& Tosoni, G. M. Efficacy of several digital radiographic imaging systems for laboratory determination of endodontic file length. Int. Endod. J., 44(5):469-73, 2011.

Ramos Brito, A. C.; Verner, F. S.; Junqueira, R. B.;Yamasaki, M. C.; Queiroz, P. M.; Freitas, D. Q. \& Oliveira-Santos, C. Detection of fractured endodontic instruments in root canals: comparison between different digital radiography systems and cone-beam computed tomography. J. Endod., 43(4):544-9, 2017.

Rosen, E.; Azizi, H.; Friedlander, C.; Taschieri, S. \& Tsesis, I. Radiographic identification of separated instruments retained in the apical third of root canal-filled teeth. J. Endod., 40(10):154952, 2014

Rosen, E.; Venezia, N. B.; Azizi, H.; Kamburoglu, K.; Meirowitz, A.; Ziv-Baran, T. \& Tsesis, I. A comparison of cone-beam computed tomography with periapical radiography in the detection of separated instruments retained in the apical third of root canalfilled teeth. J. Endod., 42(7):1035-19, 2016.

Sog ur, E.; Baksi, B. G. \& Gröndahl, H. G. Imaging of root canal fillings: a comparison of subjective image quality between limited cone-beam CT, storage phosphor and film radiography. Int. Endod. J., 40(3):179-85, 2007.

Vasconcelos, K. F.; Rovaris, K.; Nascimento, E. H. L.; Oliveira, M. L.; Távora, D. M. \& Bóscolo, F. N. Diagnostic accuracy of phosphor plate systems and conventional radiography in the detection of simulated internal root resorption. Acta Odontol. Scand., 75(8):573-6, 2017.

Wenzel, A. \& Møystad, A. Work flow with digital intraoral radiography: a systematic review. Acta Odontol. Scand., 68(2):106-14, 2010.
Corresponding author:

Eliana Dantas Costa

Division of Oral Radiology

Department of Oral Diagnosis

Piracicaba Dental School

University of Campinas

Av. Limeira 901

Areião, Piracicaba

SP. Zip Code 13414-018

BRAZIL

E-mail: edantasc@yahoo.com.br 